\title{
Response of Some Wheat Cultivars to Nano-, Mineral Fertilizers and Amino Acids Foliar Application
}

\author{
E. E. Kandil1 ${ }^{1}$, Eman A. O. Marie ${ }^{2}$
}

\begin{abstract}
Wheat is the major source of food for human nutrition and a part of daily dietary need in one form or more. There is need to increase its productivity vertically and horizontally. In order to improve productivity of three wheat cultivars, nano- technological fertilizer, common mineral fertilizer and amino acids as foliar applications were tested. Two field experiments were conducted at ElHoraia village, Abou El- Matamir district, El- Behira Governorate, Egypt, during 2014/2015 and 2015/2016 growing seasons, in split plot design with three replications. The main plots included foliar application (mineral, amino acids, nano fertilizer, mineral + amino acids, mineral + nano- fertilizer, and amino acids + nanofertilizer), while three bread wheat cultivars (Sids 12, Sids 11 and Giza 168) were allocated in the sub plot. The obtained results revealed such significant increases in plant height, spikes number $/ \mathbf{m}^{2}$, spikelets number/spike, grains number/spike, 1000- kernel weight, grain, straw, and biological yields/fed., as well as harvest index (\%) using nano- fertilizer + amino acids during both growing seasons. Meanwhile, the applied mineral fertilizer, alone; gave the lowest mean values of the studied traits. However, "Sids 12" cultivar recorded the highest means values of the studied characters. Spray "Sids 12" cultivar by nanofertilizer and amino acids; recorded the highest mean values of yield and its components. On the other hand, "Giza 168" cultivar, possessed the lowest ones.
\end{abstract}

Key words: wheat; cultivars; productivity; nanofertilizer; foliar; mineral; amino acids

\section{INTRODUCTION}

Filling up of the gap between production and consumption of wheat crop to confront its consumption exaggerated is an urgent prerequisite. Whereas, the local production of wheat grains (about 9.4 million tons) covers only $60 \%$ of the local consumption demand which reflects on the demand import about $40 \%$ of wheat grains from abroad (FAO, 2014). Whereas, wheat is the major source of food for human nutrition and a part of daily dietary need in one form or more. It is the main winter cereal crop in Egypt. Wheat is the most widely grown crop in the world with its unique protein characteristics and serves as an important source of food and energy (Abedi et al., 2010). Wheat grains contain $8-20 \%$ protein, which are divided into prolamins like

\footnotetext{
${ }^{1}$ Plant production Department, The Faculty of Agriculture

(Saba Basha), Alexandria University, Egypt

${ }^{2}$ Agronomy Department, The Faculty of Agriculture,

Omar El-Mokhatar University, Libya

Received February 22, 2017, Accepted March 22, 2017
}

gliadins and glutenins and non-prolamins consist of water-soluble albumins and salt-soluble globulins (Singh and Skerritt, 2001). Therefore, it must be increased wheat cultivated area in long term and increase productivity per area unit in short term by applying the good agricultural practices (GAP) through determining the best method of application, level and mixture of applicable nutritional elements.

Nanotechnology as a new technology has solved many difficult problems in different fields of science and industry and has found its reposition and functions in agriculture. Nanotechnology has crucial mode of action in all stages of production, processing, storage, packing and transportation of agricultural products (Scott and Chen, 2003). Also, nano-iron oxide compared to other treatments as organic materials and $\mathrm{Fe}$ citrate facilitated photosynthesis and transformation of $\mathrm{Fe}$ in peanut (Liu et al., 2005). The promoting effect of nanoparticles on seedling growth and development were reported by Zhu et al. (2008).

Nanofertilizers are the most important function of nanotechnology in the production phase of agriculture. Application of nanofertilizers instead of common fertilizers, where nutrients are provided to plants gradually and in a controlled manner. Meanwhile, the nanotechnology increases the application efficiency of fertilizers, decreases pollution and risks of chemical fertilization (Naderi et al., 2011). Nano materials are much smaller and lighter, they interact better in the environment and may be solved the problem of $\mathrm{Fe}$ nutrition in soil salinity and lime soils. Iron Nano-oxide is smaller than the common iron oxides and forms more complexes and makes the $\mathrm{Fe}$ more available to plants (Mazaherinia et al., 2010 a). Ladan et al. (2012) tested the effect of iron nanofertilizer on spinach and reported that application of $4 \mathrm{~kg} / \mathrm{ha}$ iron nanofertilizer; increased leaf weight by $58 \%$ and leaf area index by $47 \%$ compared with the control plants. Delgado and SanchezRaya (2007) reported that application of Fe fertilizer on sunflower; reduced stress effects and increased NPK absorption and plant growth and yield. Balali and Malakouti (2002) found that application of iron fertilizer; increased protein and $\mathrm{Fe}$ concentration in grains and straw of wheat and increased grain yield by 
$20 \%$. The positive effect of spraying basil plants with iron nanofertilizer was, also, noticed by Peyvandi et al. (2011) who reported that $\mathrm{Fe}$ nanoparticles increased root length, stem height, chlorophyll content and shoot dry weight compared with the common iron fertilizers. Amuamuha et al. (2012) investigated also, the effect of different concentrations of iron nanoparticles (1, 2 and 3 $\mathrm{g} / \mathrm{l})$ on marigold in growth stages of stem elongation and flowering. They reported that the highest flower yield and essential oil percentage were achieved when $1 \mathrm{~g} / \mathrm{l}$ iron nanoparticles was applied at stem elongation stage.

Spraying compounds with the technology of Nano indicated that the highest values of spike weight, 1000 kernel weight, biological, and grain yields and protein content were achieved in the first spraying time after 45 days after sowing. Among the Fe concentrations, the highest values of spike weight 1000- grain weight, biological yield, grain yield and protein content were achieved in Fe concentration and the lowest values were achieved in the control (Bakhtiari et al., 2015).

Foliar application of elements gave significant effect on yield traits and protein content on some wheat cultivars during both seasons compared with control treatment. Moreover, foliar application with combination of elements; produced the highest values of plant height, tillers number $/ \mathrm{m}^{2}$, spikes number $/ \mathrm{m}^{2}$, spike length, number of spikelets/spike, number of grains/spike, 1000- grain weight, grain yield, straw yield, biological yield and harvest index \%, respectively, in both seasons followed by $\mathrm{Zn}$ foliar application followed by foliar application of $\mathrm{Mn}$ followed by $\mathrm{Fe}$ foliar application then $\mathrm{Cu}$ foliar application (Mekkei and El Haggan, 2014).

Amino acid application containing $\mathrm{Zn}$ enhanced growth and productivity (Datir et al., 2012). Also, amino acids affected the physiological yield of the plant and its growth directly or indirectly (Abd El-Aal et al., 2010). The application of amino acid with chemical fertilizers could augment the function of plants (Ashoori et al., 2013). The significant role of amino acid as the constituent element of plant proteins in biochemical and physiological functions of the plant, its application is essential (Ebrahimi et al., 2014; Shetta and Zayed 2016).

This investigation was conducted aiming to explore the effect of foliar application of nano-, mineral and amino acids on some wheat cultivars productivity in new soils.

\section{MATERIALS AND METHODS}

Two field experiments were carried out to study foliar application of nano, mineral fertilizer and amino acids effect on yield, yield components and quality of three wheat cultivars. Field experiments were conducted in El-Horaia village, Abou El-Matamir, El-Behira Governorate, Egypt, during the two successive seasons $2014 / 2015$ and 2015/2016 in sandy loam soil.

A split plot design with three replicates was used. Foliar fertilization treatments (mineral fertilizer, amino acids, nano- compounds, mineral fertilizer + amino acids, mineral fertilizer + nano, and amino acids + nano fertilizer) occupied the main plots. Wheat cultivars (Sids 12, Sids 11 and Giza 168) allocated in sub-plots. Some physical and chemical characteristics of the studied soil before sowing are presented in Table (1) which were determined according to Page et al. (1982) and Klute (1986)

Mineral fertilizer (Caila Total) used at rate $1.5 \mathrm{~cm} / 1$ (water), Amino acids (Dicka Hana compound) at rate 1 $\mathrm{cm} / \mathrm{l}$ (water) and nano-compound namely; Aminomineral at rate $1 \mathrm{~cm} / 1$ water added as foliar application at two times i.e., after 45 and 65 days from sowing. Analysis of the three fertilizer compounds are shown in Table (2).

The size of each sub plot was $10.50 \mathrm{~m}^{2}(3.5 \times 3.0 \mathrm{~m})$ surrounded by ditches to avoid water movement into adjacent plots. The preceding crop was maize (Zea mays L.) during both growing seasons.

Sowing method was broadcasting in both seasons. Sowing dates were $21^{\text {th }}$ and $28^{\text {th }}$ November during both $2014 / 2015$ and 2015/2016 seasons, respectively, while seeding rate was $75 \mathrm{~kg}$ grains/fed. The first irrigation was applied at 21 days after sowing then plants were irrigated every 21 days till the dough stage.

However, nitrogen fertilizer in form of urea $(46.5 \%$ $\mathrm{N})$ at rate of $70 \mathrm{~kg} \mathrm{~N} / \mathrm{fed}$., was added in three doses. The first dose (20 kg N/fed.) was added at sowing time, the second dose (30 kg N/fed.) was added before the first irrigation (21 days after sowing) and the third dose (20 $\mathrm{kg} \mathrm{N} /$ fed.) was added (21 days after the first irrigation). Super phosphate $\left(15.5 \% \mathrm{P}_{2} \mathrm{O}_{5}\right)$ fertilizer was applied before sowing at rates of $100 \mathrm{~kg} /$ fed. Potassium fertilizer was applied before sowing (during seedbed preparation) at rate of $50 \mathrm{~kg} / \mathrm{fed}$., in the form of potassium sulphate $\left(48 \% \mathrm{~K}_{2} \mathrm{O}\right)$. All other agricultural treatments for wheat production were carried out as recommended by the Ministry of Agriculture.

Recoded data include Plant height $(\mathrm{cm})$, spike length (cm), spike number $/ \mathrm{m}^{2}$, spikelets number /spike, grains number /spike, 1000-grain weight (g), grain yield, straw yield, biological yield ( $\mathrm{kg} / \mathrm{fed})$ and harvest index (\%).

For wheat chemical determinations, samples of wheat grains were ground and $0.5 \mathrm{~g}$ dry powder of each were digested by concentrated mixture of $\mathrm{H}_{2} \mathrm{SO}_{4} / \mathrm{HClO}_{4}$ acids according to Sommers and Nelson (1972). Nitrogen was determined by micro- Keldahl, according 
to Jackson (1976) and multiply by 5.75 to determine protein percentage. Phosphorus was determined, spectrophotometrcally, using ammonium molybdate/stannus chloride method according to Chapman and Pratt (1978). Potassium was determined by a flame photometer, according to Page et al. (1982). Concentrations of $\mathrm{Fe}, \mathrm{Mn}$ and $\mathrm{Zn}$ were determined using Atomic Absorption apparatus (Jackson, 1976).
All collected data were subjected to analysis of variance according to Gomez and Gomez (1984). All statistical analysis was performed using analysis of variance technique by means of CoStat computer software package (CoStat, Ver. 6.311., 2005). The least significant differences (LSD at 0.05) used to compare the treatment's means.

Table 1. Some soil physical and chemical properties of the experimental sites during 2014/2015 and 2015/2016 seasons

\begin{tabular}{|c|c|c|}
\hline \multicolumn{3}{|c|}{ Soil characteristics } \\
\hline & \multicolumn{2}{|c|}{ Seasons } \\
\hline Particle size distribution & 2013 & 2014 \\
\hline Soil texture $(\%)$ & Sandy loam & Sandy loam \\
\hline Sand $\%$ & 60.90 & 61.03 \\
\hline Silt \% & 10.60 & 10.05 \\
\hline Clay $\%$ & 28.50 & 28.92 \\
\hline $\mathrm{pH}$ (1: 2.5 water suspension) & 8.10 & 7.99 \\
\hline $\mathrm{EC}\left(\mathrm{dSm}^{-1}\right)$ & 3.41 & 3.53 \\
\hline \multicolumn{3}{|l|}{ Soluble Cations (meq/L.) } \\
\hline $\mathrm{Ca}^{++}$ & 7.60 & 8.00 \\
\hline $\mathrm{Mg}^{++}$ & 4.20 & 4.85 \\
\hline $\mathrm{Na}^{+}$ & 5.10 & 5.00 \\
\hline $\mathrm{K}^{+}$ & 0.50 & 0.55 \\
\hline \multicolumn{3}{|l|}{ Soluble Anions (meq/L.) } \\
\hline $\mathrm{HCO}_{3}^{-}$ & 3.00 & 3.95 \\
\hline $\mathrm{Cl}^{-}$ & 3.80 & 3.10 \\
\hline $\mathrm{SO}^{--}$ & 10.30 & 10.20 \\
\hline O.M. $(\%)$ & 1.85 & 1.90 \\
\hline $\mathrm{CaCO}_{3}(\%)$ & 22.50 & 23.70 \\
\hline Available Mineral N(mg/kg) & 22.40 & 25.60 \\
\hline Available P (mg/kg) & 5.12 & 5.50 \\
\hline
\end{tabular}

Table 2. Structure of mineral fertilizer, amino acids and Nano- compounds

\begin{tabular}{lccc}
\hline Structure & $\begin{array}{c}\text { Mineral fertilizer } \\
\text { (Caila Total) }\end{array}$ & $\begin{array}{c}\text { Amino acids } \\
\text { (Dicka Hana compound) }\end{array}$ & $\begin{array}{c}\text { Nano-compound } \\
\text { (Aminomineral) }\end{array}$ \\
\hline $\mathrm{N} \%$ & 20 & - & 8 \\
$\mathrm{P} \%$ & 20 & 4 & 5 \\
$\mathrm{~K} \%$ & 20 & - & 6 \\
$\mathrm{Fe} \%$ & 0.10 & 3 & 4 \\
$\mathrm{Zn} \%$ & 0.05 & 2 & 4 \\
$\mathrm{Mn} \%$ & 0.05 & 2 & 2 \\
$\mathrm{Cu} \%$ & 0.05 & - & - \\
$\mathrm{Amino}$ acid \% & - & 10 & - \\
$\mathrm{Humic}$ acid \% & - & 15 & - \\
Fulvic acid \% & - & 10 & - \\
Br \% & - & - & 0.02 \\
Mo \% & - & - & 0.02 \\
EDTA & - & - & 1.50 \\
Inert integrant $(\%)$ & 39.75 & 54.00 & 69.46 \\
\hline
\end{tabular}




\section{RESULTS AND DISCUSSION}

The obtained data in the current study will be presented as follows:

Data presented in Table (3) revealed the effect of foliar application of nano- compounds, mineral and amino acids and their interactions on plant height, spike length $(\mathrm{cm})$, and spikes number $/ \mathrm{m}^{2}$ of Sids 12 , Sids 11 and Giza 168 wheat cultivars during both 2014/2015 and 2015/2016 seasons.

Concerning foliar fertilization effects on plant height, data shown in Table (3) indicated that foliar application with a mixture of nano- fertilizer + amino acids treatment; recorded the tallest plant heights $(103.64$ and $104.20 \mathrm{~cm})$ during the first and second seasons, respectively as compared with other treatments and amino acids treatment alone that produced (102.40 and $102.84 \mathrm{~cm}$ ) during both seasons, respectively. Meanwhile, the shortest plants $(91.58$ and $92.30 \mathrm{~cm})$ were recorded with the foliar application of mixture of nano + mineral fertilizer during both growing seasons. The increments in characters as average values may be taken place due to the role of amino acids and nanofertilizer enhancing cell division and enlargement both longitudinal and transvessely; and subsequently plant growth and develop wheat plants. Also, the obtained data are shown in Table (3) disclosed that the highest mean values for spike length $(11.85$ and $12.35 \mathrm{~cm})$ and spikes number $/ \mathrm{m}^{2} \quad\left(312.00\right.$ and 316.66 spikes $\left./ \mathrm{m}^{2}\right)$ achieved via foliar application of nano fertilizer + amino acids during both seasons, respectively. The increase in characters may be given rise due to the role of amino acids and nano- fertilizer for increasing growth promoting substance within inter - and intra plant tissues. Likewise, the enhancement in plant height in corn might be due to fundamental role of $\mathrm{Zn}$ in maintaining structural stability of cell membranes and use in protein synthesis, membrane function and cell elongation as reported by Welch (2008). On the other hand, the shortest spike $(9.62$ and $10.04 \mathrm{~cm})$, and the lowest spikes number/m $\mathrm{m}^{2}$ (241.66 and 246.66) were gained owing to foliar application of mineral fertilizer during both seasons. These results are in harmony with those of Peyvandi et al. (2011) who reported that Fe nanoparticles increased root length, stem height, chlorophyll content and shoot dry weight compared with the common iron fertilizer and with Amuamuha et al. (2012) who stated that the highest flower yield and essential oil percentage were achieved when $1 \mathrm{~g} / \mathrm{l}$ iron nanoparticles was applied at stem elongation stage. Also, Prasad et al. (2012) who revealed that using nanoscale zinc oxide had significant effect on the germination, growth and yield.
It this respect, data of Table (3) also, demonstrated that wheat cultivars did not exerted, significantly, effect on plant height during both growing seasons. Nevertheless, wheat cultivars were, significantly, affected spike length during both growing seasons. Whereas, "Sids 12" cultivar achieved the longest spike (11.50 and $11.45 \mathrm{~cm})$, while "Giza 168" cultivar; gave the shortest spike $(10.36$ and $10.66 \mathrm{~cm})$ during two seasons, respectively. Also, the wheat cultivar "Sids 12" recorded the highest spikes number $/ \mathrm{m}^{2}$ (282.55 and 287.55 spikes $/ \mathrm{m}^{2}$ ) in both seasons, each in trun. While "Giza 168" cultivar; recoded the lowest number $(265.22$ and 270.00 spikes $/ \mathrm{m}^{2}$ ) which had no significant difference with "Sids 11" during 2014/2015 and 2015/2016 seasons. These differences between wheat cultivars are mainly due to genetically differences make up between the three cultivars. These results are in agreement with those obtained by Mekkei and El Haggan (2014) who concluded that nano- fertilizer and amino acids increased growth and yield and its components.

Concerning the interaction between applied foliar application and wheat cultivars, the presented data in Tables (3) revealed that foliar applications $X$ wheat cultivars affected significantly the plant height, spike length, and spikes number $/ \mathrm{m}^{2}$ in both growing seasons. Likewise, "Sids 12 " cultivar sprayed with nano- fertlizer + amino acids reseeded in the highest values for plant height (106.00 and $104.47 \mathrm{~cm})$, spike length (12.50 and $12.83 \mathrm{~cm}$ ), and spikes numbers $/ \mathrm{m}^{2}$ (324.33 and 329.33) during both seasons. Meanwhile the lowest plant height $(90.65$ and $87.20 \mathrm{~cm})$ when wheat plants were foliar application of nano + mineral fertilizer or mineral treatment alone, spike length $(8.70$ and $9.43 \mathrm{~cm})$, and spikes number $/ \mathrm{m}^{2}$ (233.33 and 238.33 spikes) when, the wheat cultivar "Giza 168" plants were fertilized with mineral fertilizer alone in both seasons.

Data tabulated in Table (4) reported that the highest values for spikelets number/spike (18.72 and 18.39 spikelets), grains number/spike (56.33 and 54.83 grains) and 1000- kernel weight (53.04 and $54.45 \mathrm{~g}$ ) were recorded with applying the combination of nanofertilizer + amino acids treatment during both seasons as compared with other treatments without significant difference with mixture of nano + mineral fertilizer for 1000 - kernel weight $(52.97 \mathrm{~g})$ in the first season, and mineral + amino acid application treatment (54.65 g) in the second season. However, the lowest mean values for spikelets number/spike (15.05 and 14.94), grains number/spike (46.00 and 43.95 grains) and 1000- kernel weight $(40.79$ and $49.57 \mathrm{~g})$ was gained with foliar application of mineral fertilizer alone during both seasons of the study. 


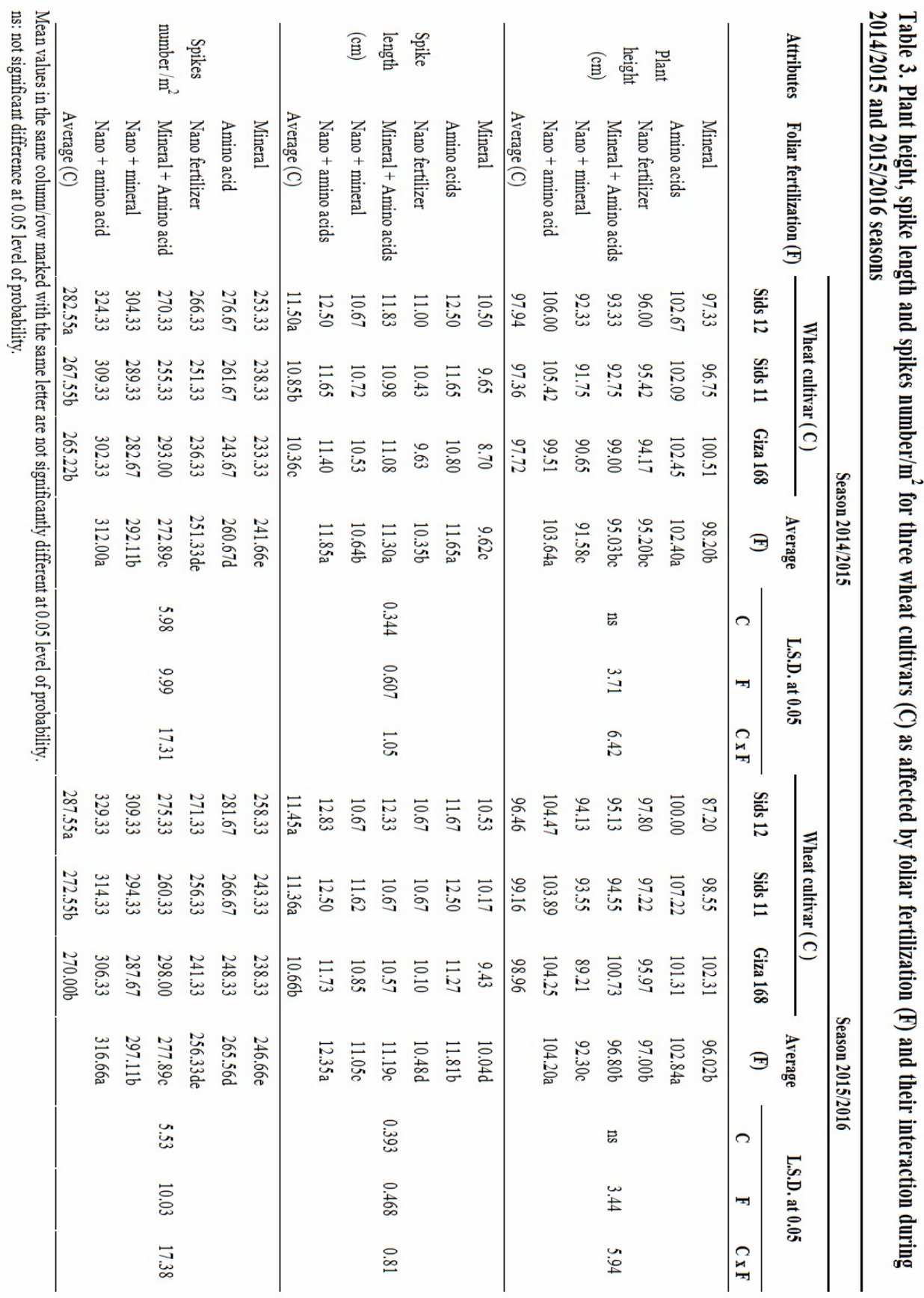




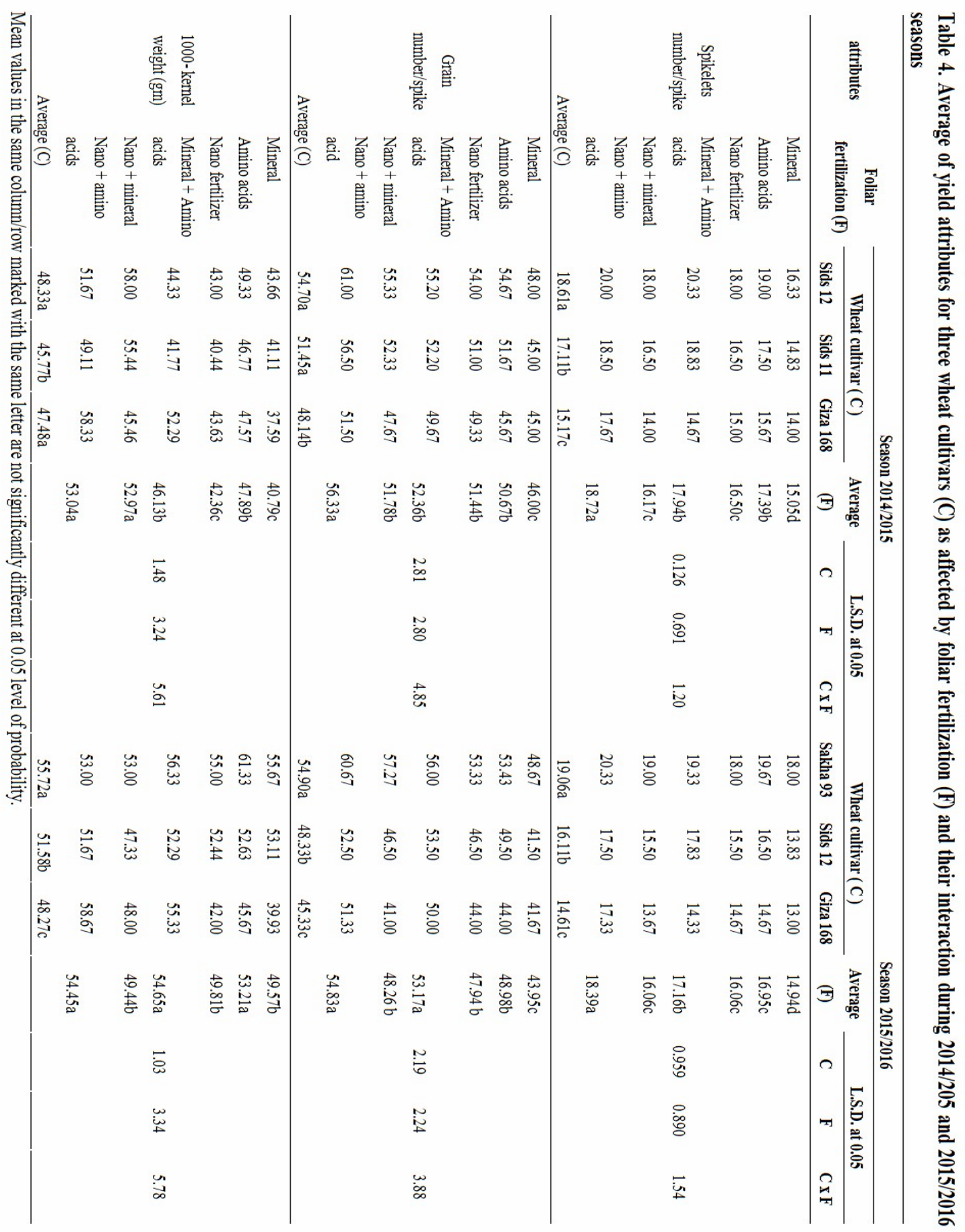


The results shown in Table (4), also, demonstrated that the highest mean values for spikelets number/spike (18.61 and 19.06 spikelets/spike), grains number/spike (54.70 and 54.90 grains) and 1000- kernel weight (48.33 and $55.72 \mathrm{~g}$ ) were obtained by wheat cultivar "Sids 12", while "Giza 168" cultivar had the lowest ones of these characters expect 1000- kernel weight during both studied seasons. On the other hand, Giza 186 cultivar had no significant difference with "Sids 12 " cv. for 1000 - kernel weight (47.48 g) in the first season, only. These differences between wheat cultivars may be due to genetically differences make up between the three cultivars. Buhedma (2011); Raza et al. (2012); AlTemimi et al. (2013); Bakry et al. (2013) found high significant differences between wheat cultivars under their studies for yield and its components.

The present data in Table (4) revealed that foliar applications $\mathrm{X}$ wheat cultivars affected significantly spikelets number/spike, grains number/spike and 1000kernel weight (gm) in both growing seasons. Likewise, "Sids 12" cultivar sprayed with nano- fertlizer + amino acids recorded in the highest mean values for spikelets number/spike (20.00 and 20.33), grains number/spike (61.00 and 60.67 grains/spike) and the heaviest 000kernel weight (58.33 and $58.67 \mathrm{~g})$ recorded with Giza168 + nano + amino acids during both growing seasons, respectively. Meanwhile the lowest spikelets number/spike (14.00 and 13.00 spikelets) when the wheat cultivar "Giza 168" plants were sprayed with mineral fertilizer alone in both seasons, but the lowest grains numbers/spike (45.00 and 41.00 grains) were recorded with "Giza 168" cv. when sprayed with mineral fertilizer in the first season, and with mineral + nano fertilizer in the second season and 1000- kernel weight (37.59 and $39.93 \mathrm{~g}$ ) were recorded by fertilizing "Giza 168" cultivar with mineral fertilizer in the first and the second season, respectively.

Data presented in Table (5) revealed that the highest values for grain yield (2620.76 and $2677.39 \mathrm{~kg} / \mathrm{fed}$.), straw yield (3408.76 and $3402.55 \mathrm{~kg} / \mathrm{fed}$.) and biological yield (6029.51 and $6079.94 \mathrm{~kg} / \mathrm{fed}$.) were recorded owing to foliar application with nano- fertilizer + amino acids treatment as compared with other treatments during both seasons of the study, respectively. Nevertheless, the lowest mean values for grain yield (1955.26 and $1920.58 \mathrm{~kg} / \mathrm{fed}$.), straw yield (2743.26 and $2679.08 \mathrm{~kg} / \mathrm{fed}$.) and biological yield (4698.51 and $4599.65 \mathrm{~kg} / \mathrm{fed}$.) were achieved with mineral fertilizer during both seasons. These results are in agreement with those of Zoz et al. (2012) who showed that higher concentration of zinc foliar application allowed obtaining $26 \%$ more in the number of spikes $/ \mathrm{m}^{2}$ compared to non-supply of nutrient. Also, Bakhtiari et al. (2015) indicated that nano-fertilizer; increased wheat grain yield and its components. Nanochalate zinc application expressed a positive effect on yield and yield components. For instance, soil application of nano- chalate zinc produced the highest 100-grain weight and seed yield (Mosanna and Behroztar, 2015). Significant increase was recorded on yield attributes of faba bean using foliar application of nano- fertilizer in both growing seasons (Gomaa et al., 2016).

Data of Table (5), also, revealed that "Sids 12" wheat cultivar achieved the highest mean values for grain yield (2575.94 and $2415.23 \mathrm{~kg} / \mathrm{fed}$.), straw yield (3318.48 and $3130.98 \mathrm{~kg} / \mathrm{fed}$.) and biological yield (5894.42 and $5546.21 \mathrm{~kg} / \mathrm{fed}$.) during both seasons. On the other side, the lowest mean values for grain yield (1954.18 and $1942.76 \mathrm{~kg} /$ fed.), straw yield (2771.16 and $2719.26 \mathrm{~kg} / \mathrm{fed}$.) and biological yield (4725.33 and $4662.01 \mathrm{~kg} / \mathrm{fed}$.) were recorded with wheat cultivar only in both studying seasons. Tahir et al. (2009) cleared that among yield components, number of fertile tillers is very important because the higher number of fertile tillers can be formed the more final crop yield.

With respect to the interaction between fertilizers foliar application and wheat cultivars, data in Table (5) disclosed that wheat cultivar "Sids 12 " X nano fertilizer + amino acids; achieved the highest values for grain yield (2935.80 and $2861.83 \mathrm{~kg} / \mathrm{fed}$.), straw yield (3723.80 and $3520.33 \mathrm{~kg} / \mathrm{fed}$.) and biological yield (6659.60 and $6382.16 \mathrm{~kg} / \mathrm{fed}$.) during both seasons. On the other side, the lowest mean values for grain yields (1755.10 and $1733.07 \mathrm{~kg} /$ fed.), straw yields (2543.10 and $2491.57 \mathrm{~kg} /$ fed.) and biological yields (4298.20 and $4224.64 \mathrm{~kg} /$ fed.) were recorded with spraying "Giza 168 " with amino acids alone in both seasons.

Results presented in Table (6) indicated that wheat plants sprayed by nano- fertilizer + amino acid registered or led to the highest mean values of protein (13.84 and 13.56\%) and grain P contents (13.41 and $14.86 \%)$ but the highest mean values for grain $\mathrm{K}$ contents (6.64 and $6.36 \%)$ were recorded with foliar application of mineral fertilizer + amino acids during both growing seasons. One the other hand, the lowest ones for grain protein \% (10.0 and $9.64 \%)$, grain $\mathrm{P}$ contents (10.03 and $11.59 \%)$ were obtained when the plants were sprayed with mineral fertilizer; meanwhile, the lowest grain contents for K (4.73 and $4.45 \%$ ) were obtained by spraying amino acids alone during both growing seasons. It is know that foliar application by all micronutrients gave significant effect on yield traits and protein content. 


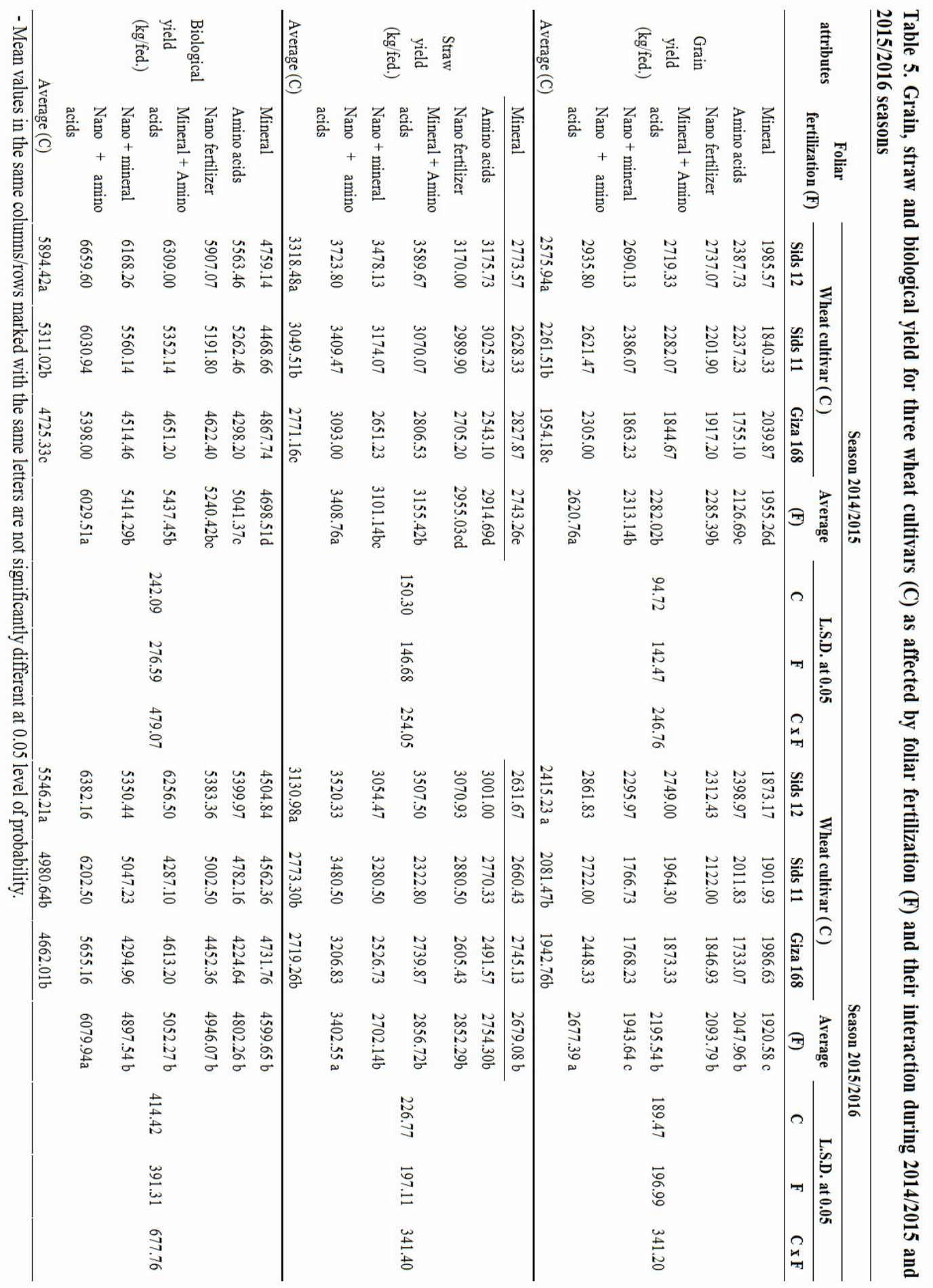




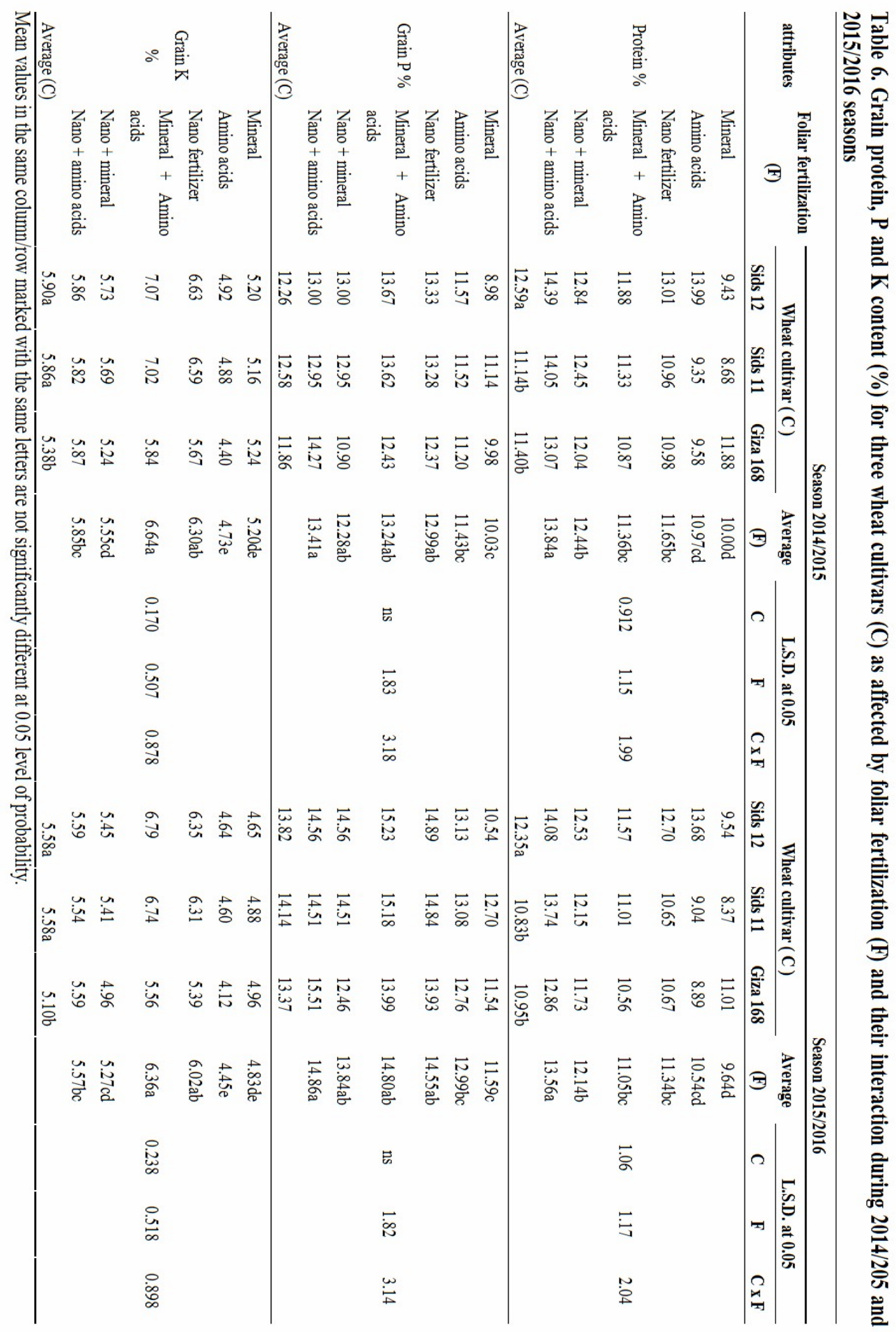


They are needed in trace amounts, but their adequate supply improves nutrients availability and positively affects the cell physiological that is reflected in yield (Toyama et al., 2001). Also, Khan et al. (2006) stated that $\mathrm{Cu}, \mathrm{Fe}, \mathrm{Mn}$ and $\mathrm{Zn}$ contents of wheat grain increased with application of mineral fertilizers. Micronutrients as nano- fertilizer can be used in crop production to increase yield (Reynolds, 2002). Nanofertilizer with small size and large surface area are expected to be the ideal material for use as fertilizer in plants. When materials are transformed to a nanoscale, they change their physical, chemical and biological characteristics as well as catalytic properties and even more increase the chemical and biological activities (Mazaherinia et al., 2010 b).Further, nano- fertilizers have been developed and have provided a new efficient alternative to normal regular fertilizers. The properties of nano-particles (more surface area) may help in increasing the reactive points of these particles and hence increase the reactivity of these nanoparticles, which could induce changes in the physio-chemical properties of these nanoparticles which help in the absorption of fertilizers in the plants (Anonymous, 2009).

Results of Table (6) illustrated that wheat cultivar "Sids 12" surpassed other cultivars, in which achieved the highest values for protein (12.59 and 12.35\%) and grain $\mathrm{K}$ content $(5.90$ and $5.59 \%)$ in both growing seasons. One the other hand, the lowest ones for grain protein \% (11.14 and $10.83 \%$ ) were achieved with "Sids 11" which had no significant difference with "Giza 168" during both seasons. However, Giza 168; recorded the lowest grain contents of K (5.38 and 5.10 $\%)$ during both growing seasons, respectively. Also, data in Table (6) reveal that there is no significant difference among the three wheat cultivars in this study regarding grain $\mathrm{P}$ content during both seasons. $\mathrm{K}, \mathrm{Zn}$, and $\mathrm{Mn}$ were significant increased due to foliar application of macronutrients. There were significant differences between the two varieties for most studied characteristics (Abd El-Ghany et al., 2013).

Respecting the interaction between applied foliar application and wheat and wheat cultivars, the recorded data in Table (6) indicated that wheat cultivar "Sids 12" plants sprayed with nano + amino acids achieved the highest values for protein contents (14.39 and $14.08 \%$ ), while the lowest grain protein \% (8.68 and $8.37 \%)$ recorded with foliar application as the mineral fertilizer + "Sids 11" during both seasons. However, "Giza 168" cv. with nano fertilizer + amino acids recorded the highest values for grain P contents (14.27 and $15.51 \%$ ) and grain $\mathrm{K}$ contents (5.87 and $5.59 \mathrm{ppm}$ ).
Meanwhile, the lowest ones for grain $\mathrm{P}$ content (8.98 and $10.54 \%$ ) achieved with "Sids $12 "+$ mineral, and lowest content of K (4.40 and $4.12 \%)$ with nanofertilizer application to "Giza 168" in both seasons, respectively.

Data in Table (7) revealed that wheat plants sprayed by mineral fertilizer + amino acid achieved the highest values for grain Fe content (3.04 and $3.01 \mathrm{ppm}$ ), One the other hand, the lowest ones for Fe (2.02 and 1.99 ppm) were given when wheat plants were sprayed with mineral fertilizer during both growing seasons. Also, Table (7) disclosed that wheat plants that sprayed with a combination of nano- fertilizer + amino acid; gave rise to the highest values for grain $\mathrm{Mn}$ contents (3.27 and $3.23 \mathrm{ppm})$ and $\mathrm{Zn}(0.926$ and $0.891 \mathrm{ppm})$, On the other extreme, the lowest ones for $\mathrm{Mn}$ (2.13 and $2.09 \mathrm{ppm})$ and $\mathrm{Zn}(0.787$ and $0.747 \mathrm{ppm})$ were recorded when plants were sprayed with mineral fertilizer which had no significant difference among it and mineral alone, and nano- fertilizer alone during the two growing seasons. These results agreed with those obtained by MoussaviNik et al. (2012), Leta et al. (2013) and Mekkei and El Haggan (2014) who revealed that there was a positive effect of micronutrient on these characters.

Further data in Table (7) demonstrated that wheat cultivar "Giza 168" was superior to the other cultivars which achieved the highest values for Fe (3.62 and 3.59 ppm) and grain Mn contents (3.67 and $3.63 \mathrm{ppm}$ ). On the other hand, the lowest ones for grain $\mathrm{Fe}$ content (1.76 and $1.73 \mathrm{ppm}$ ) and $\mathrm{Mn}$ (1.43 and $1.39 \mathrm{ppm})$ were recorded with "Sids 12". However, there is no significant differences among the tested three wheat cultivars in terms of grain $\mathrm{Zn}$ content during both seasons.

With reference to the interaction between applied foliar application and wheat cultivars, the obtained data in Table (7) declared that wheat cultivar "Giza 168" plants sprayed with nano + amino acids recorded the highest values for $\mathrm{Fe}$ contents (3.87 and $3.84 \mathrm{ppm}$ ), grain $\mathrm{Mn}$ content (4.28 and $4.24 \mathrm{ppm})$ and $\mathrm{Zn}(0.977$ and $0.953 \mathrm{ppm})$. However, the lowest ones for grain $\mathrm{Fe}$ (1.27 and $1.24 \mathrm{ppm}), \mathrm{Mn}$ (1.40 with mineral in the first season and $1.01 \mathrm{ppm}$ with nano fertilizer in the second season) and $\mathrm{Zn}$ (0.747 and $0.707 \mathrm{ppm}$ ) were recorded with Sids 12 cultivar in 2014/2015 and 2015/2016 seasons. However, there is no significant differences among the three wheat cultivars in grain $\mathrm{Zn}$ content in the two seasons. 


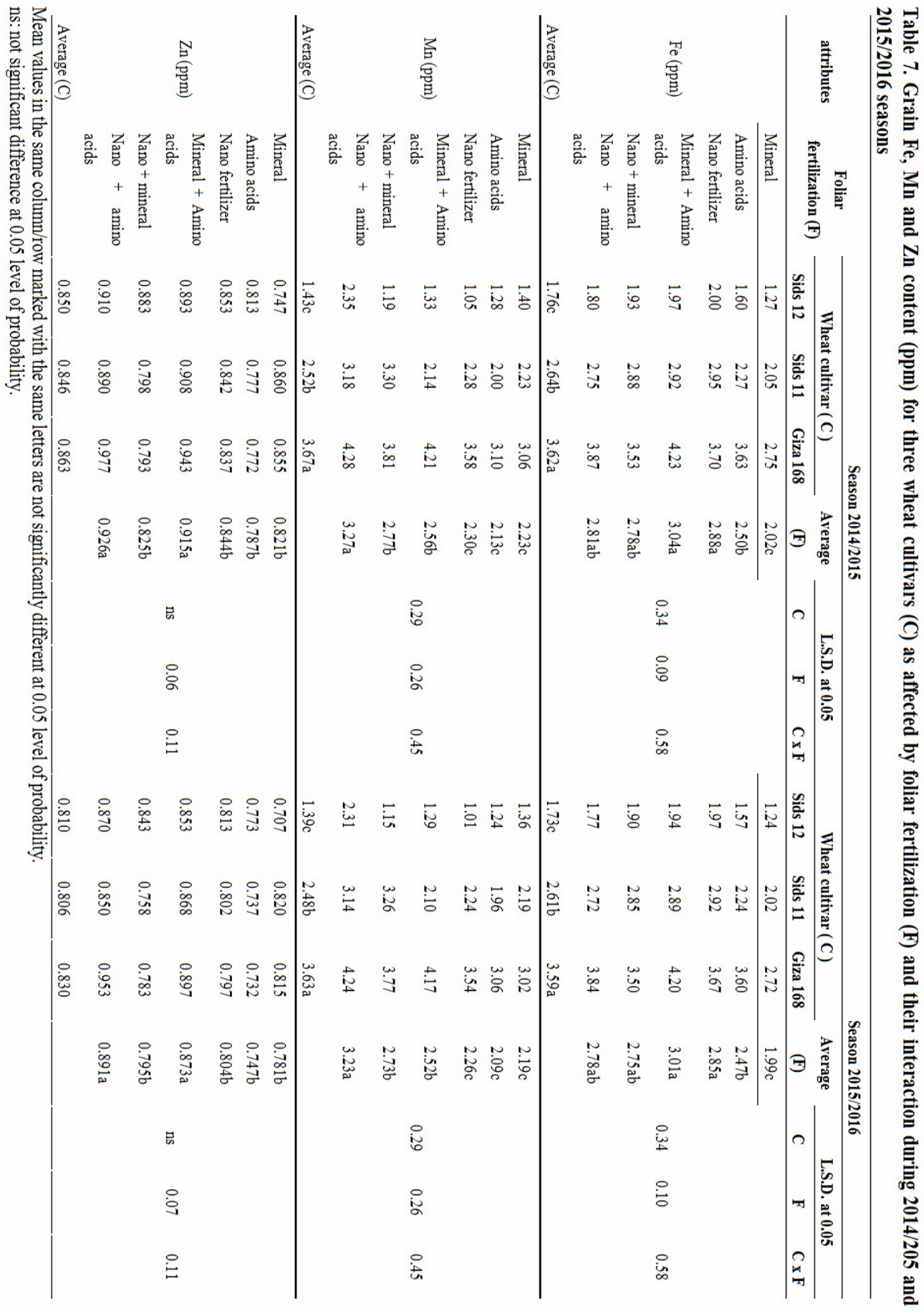




\section{CONCLUSION}

From the above recorded results during both growing seasons, it could be concluded that nanotechonological compound combined with amino acids increased yield and its components of wheat crop and "Sids 12" cultivar; was more response with this treatment under at El-Horia, El-Behira Governorate conditions, Egypt.

\section{REFERENCES}

Abd El-Aal, F.S. A., A. M. Shaheen, A. A. Ahmed and A. R. Mahmoud (2010). Effect of foliar application of amino acids as antioxidants on growth, yield and characteristics of squash. Res. J. Agric. and Biol. Sci. 6: 583- 88.

Abd El-Ghany, H.M., Ebtsam A. El-Housini and M.H.M. Afifi (2013). Effect of certain macronutrients foliar application on growth, yield and nutrients content of grains for two bread wheat varieties in sandy soil. J. Appl. Sci. Res., 9(2): 1110-1115.

Abedi, T., A. Alemzadeh and S. A. Kazemeini (2010). Effect of organic and inorganic fertilizers on grain yield and protein banding pattern of wheat. Aust J Crop Sci., 4: 384389.

Al-Temimi, H. N. Gh., I. S. Alsaadawi and A. W. AlShahwany (2013). Screening of bread wheat (Triticum aestivum L.) genotypes for drought tolerance under field conditions. A Thesis Submitted to the Biology Dept. College of Science Baghdad Univ.

Amuamuha, L., A. Pirzad and H. H. Hashem (2012). Effect of varying concentrations and time of Nanoiron foliar application on the yield and essential oil of Pot marigold. Int. Res. J. Appl. \& Basic Sci., 3: 2085-2090.

Anonymous (2009). Nano technology in agriculture. J. Agric. Technol .114:54-65.

Ashoori, M., M. Esfehani, S.Abdollahi and B. Rabiei (2013). Effects of organic fertilizer complements application on grain yield, nitrogen use efficiency and milling properties in two rice cultivars (Oryza sativa L.). Iranian J. Field Crop Sci., 43: 701-713.

Bakhtiari, Mitra, P. Moaveni and B. Sani (2015). The effect of iron nanoparticles spraying time and concentration on wheat. Biol. Forum Int. J., 7(1): 679-683.

Bakry, B. A., T. A. Elewa, M. F. El-Kramany and A. W. Wali (2013). Effect of humic and ascorbic acids foliar application on yield and yield components of two wheat cultivars grown under newly reclaimed sandy. Int. J. Agron. \& Pl. Prod. 4(6):1125-1133.

Balali, M.R. and M. J. Malakouti (2002). Effects of different methods of micronutrient application on the uptake of nutrients in wheat grains in ten provinces. Soil Sci., 15: 111.

Buhedma, A. S. I. (2011). Response of some wheat varieties to nitrogenous fertilization biofertilization and seeding rates. Ph.D. thesis, Fac. of Agric. (Saba Basha) Univ. Alex. Uiv.
Chapman, H. D. and R.T. Pratt (1978). Methods of Analysis for Soils, Plants and Water. California, Div. Univ. Agric. Sci.169.

CoStat Ver. 6.311 (2005). Cohort software798 light house Ave. PMB320, Monterey, CA93940, and USA. email: info@cohort.com and Website:http://www.cohort.com/DownloadCoStatPart2.ht $m l$.

Datir, R.B., SL Laware, BJ Apparao (2012). Effect of organically chelated micronutrients on growth and productivity in Okra. Asian J.Exp.Biol.Sci.Spl. 115-117.

Delgado, I. C. and A. J. Sanchez-Raya (2007). Effects of sodium chloride and mineral nutrients on initial stages of development of sunflower life. Comm. Soil Sci. \& Pl. Anal., 38: 2013- 2027.

Ebrahimi, M., A. Roozbahani and M. Baghi (2014). Effect of potash fertilizer and amino acids on yield components and yield of maize (Zea mays L.) Crop Res., 48 (1, 2 \& 3): 1521

FAO (2014). http://faostat.fao.org.

Gomaa, M. A., E. E. Kandil, A. A. Abuo Zeid and Bilkees, M. A. Salim (2016). Response of some faba bean varieties to fertilizers manufactured by nanotechnology. J. Advan. Agric. Resh., 21 (3):384.399.

Gomez, A. K. and A. A. Gomez (1984). Statistical Procedures for Agricultural Research. ( $2^{\text {nd }}$ edition). John Wiley and Sons., New York.

Jackson, M. L. (1976). Soil Chemical Analysis. Constable and Co. L.T.P., London, England.

Khan, M. Z., S. Muhammed, M. Naeem, AEAKhtar and M. Khalid (2006). Response of some wheat (Triticum aestivum L.) varieties to foliar application under rainfed conditions. Pak. J. Bot., 38 (4): 1027- 1034.

Klute, A. (1986). Methods of Soil Analysis. Part I, Soil Physical properties. ASA and SSSA, Madison, WI.

Ladan, M. A., H.Vattani, N. Baghaeiand and N. Keshavarz, (2012). Effect of different levels of fertilizer nanoiron chelates on growth and yield characteristics of two varieties of spinach (Spinacia oleracea L.): varamin 88 and viroflay. Res. J. Appl. Sci., Eng. \& Tech., 4(12): 4813-4818.

Leta, G., G. Belay and W. Worku (2013). Nitrogen fertilization effects on grain quality of durum wheat (Triticum turgidum L.Var.Durum) varieties in Central Ethiopia. J. Agric. Sci., 1(1):1-7.

Liu, X. M., F.D. Zhang, S. Q. Zhang, X. S. He, R. Fang, Z. Feng and Y. Wang (2005). Effects of nano-ferric oxide on the growth and nutrients absorption of peanut. Pl. Nutr. Fert. Sci., 11:14-18.

Mazaherinia, S., A.R. Astaraei, A. Fotovat, A. Monshi (2010a). Nano iron oxide particles efficiency on $\mathrm{Fe}, \mathrm{Mn}$, $\mathrm{Zn}$ and $\mathrm{Cu}$ concentrations in wheat plant. World App. Sc. J. 7(1):36-40. 
Mazaherinia, S., A. Astaraei, A. Fotovvat and A. Monshi (2010b). The comparison of iron absorption and accumulation in wheat by the application of common iron oxides and nano-oxides along with compost and granulated sulfur. Iran. J. Agro., 92: 103-111.

Mekkei, M. E. R. and E. A. M. El Haggan (2014). Effect of $\mathrm{Cu}, \mathrm{Fe}, \mathrm{Mn}$ and $\mathrm{Zn}$ foliar application on productivity and quality of some wheat cultivars (Triticum aestivum L.) J. Agri-Food \& Appl. Sci., 2 (9): 283-291.

Mosanna, R. and E. K. Behrozytar (2015). Morphophysiological response of maize (Zea mays L.) to zinc nano-chelate foliar and soil application at different growth stages. J. on New Biol. Rept. 4(1) $46-50$.

Moussavi-Nik, M., M. Babaeian and A. Tavassoli (2012). Seed position effect on grains micronutrient content of ten wheat genotypes. Afr. J. Microbio. Res., 6(28): 57575762.

Naderi, M., A. A. D. Shahraki and R. Naderi (2011). Application of nanotechnology in the optimization of formulation of chemical fertilizers. Iran. J. Nanotech., 12: 16-23.

Page, A. L., R. H. Miller and D. R. Keeney (1982). Methods Of Chemical Analysis. Part 2: Chemical and Microbiological Properties (2 ${ }^{\text {nd }} E d$.). American Soc. of Agronomy, Inc. and Sci. Soc. Amer. Inc. Publ. Madison, Wisconsin, U.S.A.

Peyvandi, M., H. Parandeh and M. Mirza (2011). Comparing the effect of iron Nano-chelate common iron chelate on growth parameters and antioxidant enzymes activity of basil (Ocimum basilicum L). Iran. J. Mod. Cell. \& Molec. Biotech., 1: 89- 99.

Prasad, T.N., P. Sudhakar, Y. Sreenivasulu, P. Latha, V. Munaswamy, K. Raja, Reddy, T.S. Sreeprasad, P.R. Sajanlal and T. Pradeep (2012). Effect of nanoscale zinc oxide particles on the germination, growth and yield of peanut. J. P1. Nut., 35: 905927.

Raza, M.A. S., M. F. Saleem, I. H. Khan, M. Jamil, M. Ijaz and M.A. Khan (2012). Evaluating the drought stress tolerance efficiency of wheat (Triticum aestivum L.) cultivars. Russ. J. Agric. Socio-Econ. Sci., 12 (12):41- 46.

Reynolds, G.H. (2002). Forward to the future nanotechnology and regulatory policy. Pacific Res. Inst.,24: 1-23.

Scott, N. and H. Chen (2003). Nanoscale science and engineering for agriculture and food systems. A Report Submitted to Cooperative State Research, Education, and Extension Service, USDA.

Shetta,N.D., and M. Z. Zayed.2016. Responses of Acacia gerrardii and Vachellia origena Seedlings to Mineral Fertilization and Salinity Stress in Saudi Arabia.Alex.Sci.Exch.J.37(3):430-439.

Singh, J. and J. H. Skerritt (2001) Chromosomal control of albumins and globulins in wheat grain assessed using different fractionation procedures. J Cereal Sci., 33: 163181.
Sommers, L. E. and D. W. Nelson (1972). Determination of total phophorus in soil. A rapid perchloric acid digestion procedure. Soil Sci. Soc. Amer. Proc., 36: 902-904.

Tahir, M., A. Tanveer, T.H. Shah, N. Fiaz and A. Wasaya (2009). Yield response of wheat (Triticum aestivum L.) to boron application at different growth stages. Pak. J. life Soc., Sci., 7: 39- 42.

Toyama, S. E. A., Amal, A. El-Hofi and H. Ashoush (2001). Yield and technological characteristics of some wheat varieties as affected by $\mathrm{N}$ fertilizer and seed rates Agric. Sci. Mansoura Univ., 25 (50: 2449- 2467.

Welch, R.M. (2008). Linkages between trace elements in food crops and human health. P. 41-61. In B.J. Alloway, ed. Micronutrient Deficiencies in Global Crop Production. Springer Science.

Zhu, H., J. Han, J. Q. Xiao and Y. Jin (2008). Uptake, translocation and accumulation of manufactured iron oxide nanoparticles by pumpkin plants, J. Environ. Monitor., 10:713-717.

Zoz, T., F. Steiner, J. Vitor, Paulo Testa, E. Pereira, Seidel, R. Fey, D. Dalazen, Castagnara and A. Zoz (2012). Foliar fertilization with molybdenum in wheat. J Ciência Rural Santa Maria, 42: 5,784.

Abd El-Aal, F.S. A., A. M. Shaheen, A. A. Ahmed and A. R. Mahmoud (2010). Effect of foliar application of amino acids as antioxidants on growth, yield and characteristics of squash. Res. J. Agric. and Biol. Sci. 6: 583- 88.

Abd El-Ghany, H.M., Ebtsam A. El-Housini and M.H.M. Afifi (2013). Effect of certain macronutrients foliar application on growth, yield and nutrients content of grains for two bread wheat varieties in sandy soil. J. Appl. Sci. Res., 9(2): 1110-1115.

Abedi, T., A. Alemzadeh and S. A. Kazemeini (2010). Effect of organic and inorganic fertilizers on grain yield and protein banding pattern of wheat. Aust J Crop Sci., 4: 384389.

Al-Temimi, H. N. Gh., I. S. Alsaadawi and A. W. AlShahwany (2013). Screening of bread wheat (Triticum aestivum L.) genotypes for drought tolerance under field conditions. A Thesis Submitted to the Biology Dept. College of Science Baghdad Univ.

Amuamuha, L., A. Pirzad and H. H. Hashem (2012). Effect of varying concentrations and time of Nanoiron foliar application on the yield and essential oil of Pot marigold. Int. Res. J. Appl. \& Basic Sci., 3: 2085-2090.

Anonymous (2009). Nano technology in agriculture. J. Agric. Technol .114:54-65.

Ashoori, M., M. Esfehani, S.Abdollahi and B. Rabiei (2013). Effects of organic fertilizer complements application on grain yield, nitrogen use efficiency and milling properties in two rice cultivars (Oryza sativa L.). Iranian J. Field Crop Sci., 43: 701-713.

Bakhtiari, Mitra, P. Moaveni and B. Sani (2015). The effect of iron nanoparticles spraying time and concentration on wheat. Biol. Forum Int. J., 7(1): 679-683. 
Bakry, B. A., T. A. Elewa, M. F. El-Kramany and A. W. Wali (2013). Effect of humic and ascorbic acids foliar application on yield and yield components of two wheat cultivars grown under newly reclaimed sandy. Int. J. Agron. \& Pl. Prod. 4(6):1125-1133.

Balali, M.R. and M. J. Malakouti (2002). Effects of different methods of micronutrient application on the uptake of nutrients in wheat grains in ten provinces. Soil Sci., 15: 111.

Buhedma, A. S. I. (2011). Response of some wheat varieties to nitrogenous fertilization biofertilization and seeding rates. Ph.D. thesis, Fac. of Agric. (Saba Basha) Univ. Alex. Uiv.

Chapman, H. D. and R.T. Pratt (1978). Methods of Analysis for Soils, Plants and Water. California, Div. Univ. Agric. Sci.169.

CoStat Ver. 6.311 (2005). Cohort software798 light house Ave. PMB320, Monterey, CA93940, and USA. email: info@cohort.com and Website:http://www.cohort.com/DownloadCoStatPart2.ht $m l$.

Datir, R.B., SL Laware, BJ Apparao (2012). Effect of organically chelated micronutrients on growth and productivity in Okra. Asian J.Exp.Biol.Sci.Spl. 115-117.

Delgado, I. C. and A. J. Sanchez-Raya (2007). Effects of sodium chloride and mineral nutrients on initial stages of development of sunflower life. Comm. Soil Sci. \& Pl. Anal., 38: 2013- 2027.

Ebrahimi, M., A. Roozbahani and M. Baghi (2014). Effect of potash fertilizer and amino acids on yield components and yield of maize (Zea mays L.) Crop Res., 48 (1, 2 \& 3): 1521

FAO (2014). http://faostat.fao.org.

Gomaa, M. A., E. E. Kandil, A. A. Abuo Zeid and Bilkees, M. A. Salim (2016). Response of some faba bean varieties to fertilizers manufactured by nanotechnology. J. Advan. Agric. Resh., 21 (3):384.399.

Gomez, A. K. and A. A. Gomez (1984). Statistical Procedures for Agricultural Research. ( $2^{\text {nd }}$ edition). John Wiley and Sons., New York.

Jackson, M. L. (1976). Soil Chemical Analysis. Constable and Co. L.T.P., London, England.

Khan, M. Z., S. Muhammed, M. Naeem, AEAKhtar and M. Khalid (2006). Response of some wheat (Truticum aestivum L.) varieties to foliar application under rainfed conditions. Pak. J. Bot., 38 (4): 1027- 1034.

Klute, A. (1986). Methods of Soil Analysis. Part I, Soil Physical properties. ASA and SSSA, Madison, WI.

Ladan, M. A., H.Vattani, N. Baghaeiand and N. Keshavarz, (2012). Effect of different levels of fertilizer nanoiron chelates on growth and yield characteristics of two varieties of spinach (Spinacia oleracea L.): varamin 88 and viroflay. Res. J. Appl. Sci., Eng. \& Tech., 4(12): 4813-4818.
Leta, G., G. Belay and W. Worku (2013). Nitrogen fertilization effects on grain quality of durum wheat (Triticum turgidum L.Var.Durum) varieties in Central Ethiopia. J. Agric. Sci., 1(1):1-7.

Liu, X. M., F.D. Zhang, S. Q. Zhang, X. S. He, R. Fang, Z. Feng and Y. Wang (2005). Effects of nano-ferric oxide on the growth and nutrients absorption of peanut. Pl. Nutr. Fert. Sci., 11:14-18.

Mazaherinia, S., A.R. Astaraei, A. Fotovat, A. Monshi (2010a). Nano iron oxide particles efficiency on Fe, Mn, $\mathrm{Zn}$ and $\mathrm{Cu}$ concentrations in wheat plant. World App. Sc. J. 7(1):36-40.

Mazaherinia, S., A. Astaraei, A. Fotovvat and A. Monshi (2010b). The comparison of iron absorption and accumulation in wheat by the application of common iron oxides and nano-oxides along with compost and granulated sulfur. Iran. J. Agro., 92: 103-111.

Mekkei, M. E. R. and E. A. M. El Haggan (2014). Effect of $\mathrm{Cu}, \mathrm{Fe}, \mathrm{Mn}$ and $\mathrm{Zn}$ foliar application on productivity and quality of some wheat cultivars (Triticum aestivum L.) J. Agri-Food \& Appl. Sci., 2 (9): 283-291.

Mosanna, R. and E. K. Behrozytar (2015). Morphophysiological response of maize (Zea mays L.) to zinc nano-chelate foliar and soil application at different growth stages. J. on New Biol. Rept. 4(1) 46 - 50.

Moussavi-Nik, M., M. Babaeian and A. Tavassoli (2012). Seed position effect on grains micronutrient content of ten wheat genotypes. Afr. J. Microbio. Res., 6(28): 57575762.

Naderi, M., A. A. D. Shahraki and R. Naderi (2011). Application of nanotechnology in the optimization of formulation of chemical fertilizers. Iran. J. Nanotech., 12: 16-23.

Page, A. L., R. H. Miller and D. R. Keeney (1982). Methods Of Chemical Analysis. Part 2: Chemical and Microbiological Properties ( $2^{\text {nd }}$ Ed.). American Soc. of Agronomy, Inc. and Sci. Soc. Amer. Inc. Publ. Madison, Wisconsin, U.S.A.

Peyvandi, M., H. Parandeh and M. Mirza (2011). Comparing the effect of iron Nano-chelate common iron chelate on growth parameters and antioxidant enzymes activity of basil (Ocimum basilicum L). Iran. J. Mod. Cell. \& Molec. Biotech., 1: 89- 99.

Prasad, T.N., P. Sudhakar, Y. Sreenivasulu, P. Latha, V. Munaswamy, K. Raja, Reddy, T.S. Sreeprasad, P.R. Sajanlal and T. Pradeep (2012). Effect of nanoscale zinc oxide particles on the germination, growth and yield of peanut. J. P1. Nut., 35: 905927.

Raza, M.A. S., M. F. Saleem, I. H. Khan, M. Jamil, M. Ijaz and M.A. Khan (2012). Evaluating the drought stress tolerance efficiency of wheat (Triticum aestivum L.) cultivars. Russ. J. Agric. Socio-Econ. Sci., 12 (12):41- 46.

Reynolds, G.H. (2002). Forward to the future nanotechnology and regulatory policy. Pacific Res. Inst., 24: 1-23. 
Scott, N. and H. Chen (2003). Nanoscale science and engineering for agriculture and food systems. A Report Submitted to Cooperative State Research, Education, and Extension Service, USDA.

Shetta,N.D., and M. Z. Zayed.2016. Responses of Acacia gerrardii and Vachellia origena Seedlings to Mineral Fertilization and Salinity Stress in Saudi Arabia.Alex.Sci.Exch.J.37(3):430-439

Singh, J. and J. H. Skerritt (2001) Chromosomal control of albumins and globulins in wheat grain assessed using different fractionation procedures. J Cereal Sci., 33: 163181.

Sommers, L. E. and D. W. Nelson (1972). Determination of total phophorus in soil. A rapid perchloric acid digestion procedure. Soil Sci. Soc. Amer. Proc., 36: 902-904.
Tahir, M., A. Tanveer, T.H. Shah, N. Fiaz and A. Wasaya (2009). Yield response of wheat (Triticum aestivum L.) to boron application at different growth stages. Pak. J. life Soc., Sci., 7: 39- 42.

Toyama, S. E. A., Amal, A. El-Hofi and H. Ashoush (2001). Yield and technological characteristics of some wheat varieties as affected by $\mathrm{N}$ fertilizer and seed rates Agric. Sci. Mansoura Univ., 25 (50: 2449- 2467.

Welch, R.M. (2008). Linkages between trace elements in food crops and human health. P. 41-61. In B.J. Alloway, ed. Micronutrient Deficiencies in Global Crop Production. Springer Science.

Zhu, H., J. Han, J. Q. Xiao and Y. Jin (2008). Uptake, translocation and accumulation of manufactured iron oxide nanoparticles by pumpkin plants, J. Environ. Monitor., 10:713-717.

Zoz, T., F. Steiner, J. Vitor, Paulo Testa, E. Pereira, Seidel, R. Fey, D. Dalazen, Castagnara and A. Zoz (2012). Foliar fertilization with molybdenum in wheat. J Ciência Rural Santa Maria, 42: 5,78 
الملخص العربي

\title{
إستجابة بعض أصناف القمح للرش الورقي لأسمدة النانو والأسمدة المعدنية والأحماض الأمينية
}

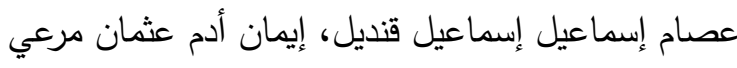

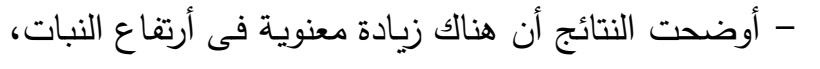

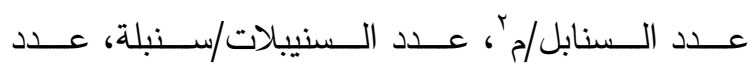

الحبـوب/سـنبلة، وزن . . . حبـة، محـصول الحبـوب

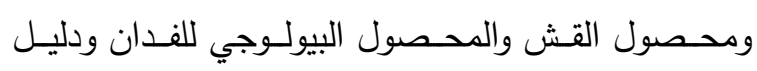

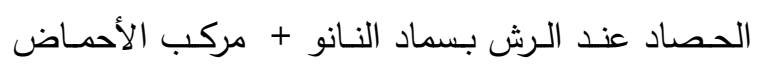

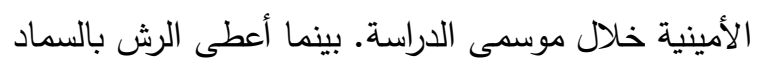

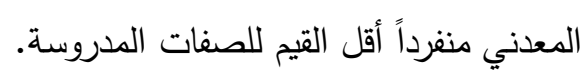

- كانت هناك اختلافات معنوية بين الأصناف الثلاثة نتيجة

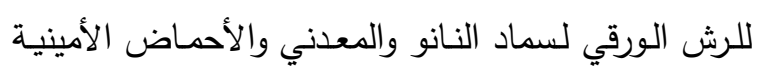

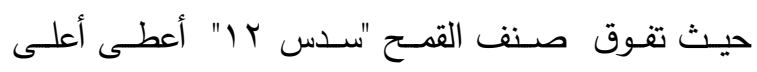

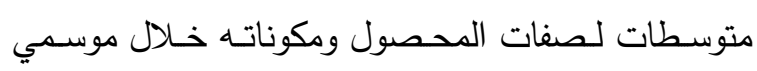

$$
\text { الدراسة }
$$

- أظهر التداخل بين عاملي الدراسة فروق معنوية لصفات

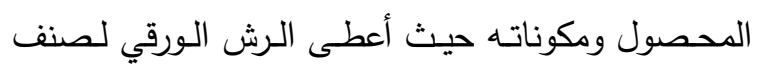

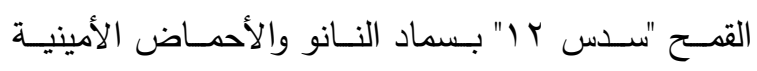
أعطت أعلى متوسطات لصفات المحصول ومكوناته.

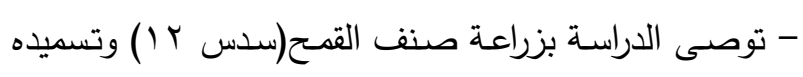

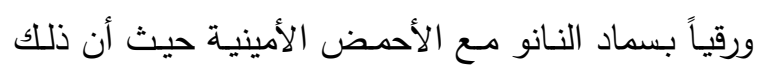
حقق أعلى انتاجية تحت ظروف منطقة الزراعة.

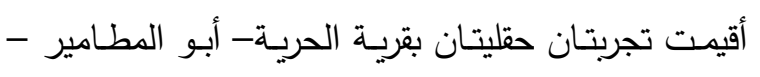

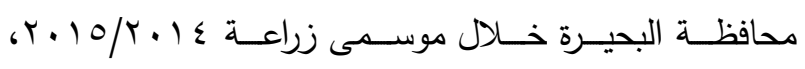

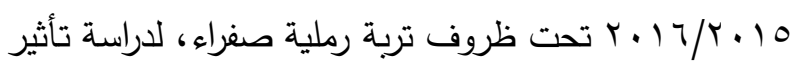

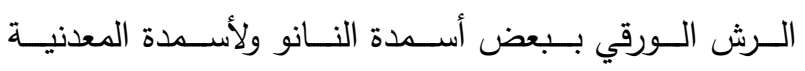

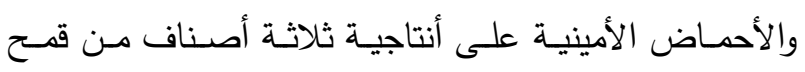
الخبز • ستخدم تصميم القطع المنشقة مرة واحدة فى ثلاثة

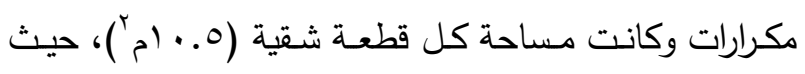

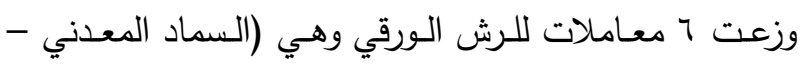

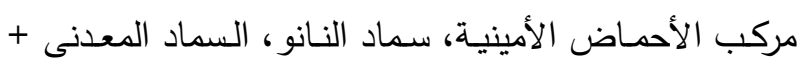

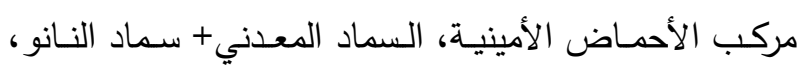

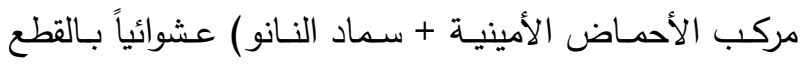

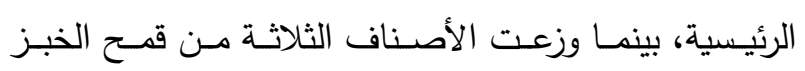

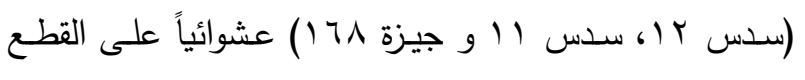

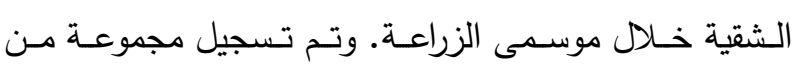

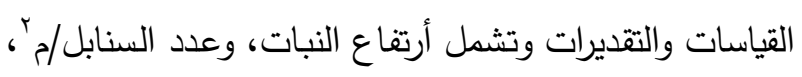

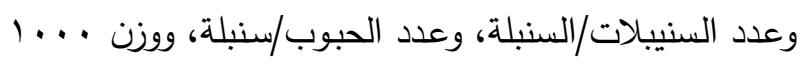
حبة، والمحصول ومحتوى الحبوب من البروتين، والفوسفور والبوتاسيوم، والحديد والمنجنيز والزنكك عند الحصاد.

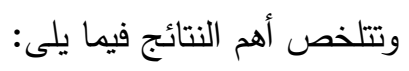

